\title{
Research Paper Economics of tur production in Amravati district
}

\author{
- S.K. KHARAT, D.H. ULEMALE AND S.N. INGLE
}

See end of the paper for authors' affiliations

Correspondence to :

S.K. KHARAT

Shri Shivaji Agriculture

College, AMRAVATI (M.S.)

INDIA

Email : kharatsuni15591@

gmail.com
Paper History :

Received : 01.10.2016;

Revised : 17.01.2017;

Accepted : 27.01.2017
Abstract : In this study, an attempt has been made to study the "analysis of yield gap in tur in Amravati district" with view to work out the economics tur production and resource use efficiency. The study was based on primary data on input used and there upon costs was collected from two tahsils viz., Amravati and Nandgoan khandeshwar from two tahsils 45 samples were selected. Per hectare input utilization for tur indicated that the medium farmers were used higher inputs as compared to other farm size group of farmers. Per hectare total cost of cultivation of tur for the sample as whole was Rs. 43118.82 per hectore. Gross retuns from tur at overall level was Rs.71349.48. The input-Output ratio at overall size cost ' $\mathrm{C}$ ' was 1.65 . for the study resource use efficiency of tur, Cobb-Douglas production function was used. In the overall group resources human labour, bullock labour, machine labour, fertilizer, plant protection and area were significant. Marginal value of product to factor cost ratio at overall group in case of human labour, machine labour, fertilizer was positive and bullock labour, seeds, manure, plant protection are negative. Marginal physical product to factor cost ratio indicates the change in total physical product to the change in input level of particular independent variable.

KeY Words : Cost of cultivation, Gross return, Resourse use efficiency, Tur

How To Cite This PAPer : Kharat, S.K., Ulemale, D.H. and Ingle, S.N. (2017). Economics of tur production in Amravati district. Internat. Res. J. Agric. Eco. \& Stat., 8 (1) : 65-71, DOI : 10.15740/HAS/IRJAES/8.1/65-71. 